\title{
A Column of Words
}

\author{
Desmond Hurley
}

Shortly, the New Zealand Dictionary Centre will have a presence http://www.vuw.ac.nz/lals/nzdc - on the Victoria University website which should be in the operation by the time this article appears. Its features will include the ability to access and print out past copies of the Dictionary Centre newsletter, NZWords, a list of dictionaries published from the Centre, as well as a page for direct entry of words or phrases which you think may be new or may reflect new uses.

The current project on the Centre's agenda is a New Zealand version of the New Oxford Dictionary of English. As well as updating, in more concise form, the Dictionary of New Zealand English, this will include several thousand entries on people, places and events of New Zealand significance.

There are several US-NZ wordlists on the Internet, mostly put together by New Zealanders, which point up the different meanings of common words on the two countries - words like jelly (jam in the United States, jelly here). While these lists have considerable merit, it should also be noted that the origins of some words are wrongly ascribed. This has occurred, I believe, because some words attributed to New Zealand came into our vocabulary in the 1920s-1940s or thereabouts from the US and are now thought by younger New Zealanders to have originated here. Possibly, they have dropped out of general usage in America but are still current here. (One example is party pooper, which was used in the United States in the 1950s and to my knowledge only became common currency here much later.) Turning to recent usages, words we have noted recently or have been asked about are:

BALE AGE, HAYLAGE. Jim Cameron sends us these two terms which he says have been around in rural New Zealand for the last ten or so years. What are haylage and baleage?

October usually yields silage, haylage. More mature grass is harvested as hay. [1995 Growing Today Nov. 42]

BRIDGE PIE. Jackie Davis asks if we know the origin of this term which is 'exclusively a Taranaki word for a small mince savoury'. We don't. Is it perhaps from a cafe or bakery near a bridge in, say, Patea or Waitara ? Is it something you serve at bridge parties? Can anyone help?

Kōtare 4, no. 1 (2001), pp. 64-72. 
BROWN FLAT \& PORTOBELLO. Two "foodie" terms for large mushrooms, as opposed to button mushrooms.

Actually, these "brown flat", "gourmet browns", "portobellos" (call them what you will) are nothing more than brown button mushrooms which have been allowed to grow up. [2000 Evening Post, $17^{\text {th }}$ Oct. 16]

I first assumed that Portobello was associated with Portobello, near Dunedin, but the place-name also occurs in Scotland, Maryland and Panama - the last was named by Columbus in 1502. It appears, however, that portobellos were introduced commercially to New Zealand from South Africa in 1992. Although I have since found them mentioned in Second Wind by English crime-writer Dick Francis, the preponderance of US listings on the Internet suggests the term probably originated in Maryland.

These big brown mushrooms...are an American strain of the standard cultivated mushroom Agaricus bisporus. In the United States, they are known as portobello. [1994 Listener $16^{\text {th }}$ July 60] An extremely large, dark brown mushroom that is simply the fully mature form of Crimino, which in turn is a variation of the common cultivated white mushroom. The name "portobello" began to be used in the 1980s as a brilliant marketing ploy to popularize an unglamorous mushroom that, more often that not, had to be disposed of because growers couldn't sell them. [All Recipes Encyclopaedia (www.allrecipes.com/encyclo/terms)]

CONSERVATORY. OED has this as 'A greenhouse for tender flowers or plants; now, usually, an ornamental house into which plants in bloom are brought from the hot-house or green-house'.

I...found her in the conservatory, fumigating the plants.[1859 W.COLLINS Queens of Hearts (1875) 24]

The modern New Zealand usage is rather of an up-market sun-room, with a glassed roof and walls, intended primarily for people rather than plants.

Coming off the kitchen are the separate laundry...a separate shower and the conservatory, where the owners often have breakfast.[2000 Dominion 22 Nov. 29]

Kōtare 4, no. 1 (2001), pp. 64-72. 
The earliest quotation we have is this one from November 2000 but it has been around much longer. Good examples would be appreciated.

DRISSY. The Encarta World English Dictionary has this intriguing entry:

drissy / drissi / adj. NZ frantic (informal).

Does anyone know of this?

EGGS. Used as a synonym for 'someone who is soft'.

My sisters begin to cry and I tell them not to be eggs and cry in front of them...I tell them that they are all and I'll find him myself. The social worker says I can't live at home by myself. I say I'll just run away if she tries to make me stay with those eggs.[2001 Sunday Star-Times $7^{\text {th }}$ Jan. D6]

FIRETRUCK / FIRETRUCKING. A synonym for incontinently drunk recorded by Greg Crossan from Massey University.

"Firetrucking", male student style, is the practice.. .of getting so hideously mullocked that control of the bladder is lost. A wet patch on the front and legs of the trousers ensues. This is the signal that a firetruck has occurred. [2000 Off Campus Sept. 5]

GUTSACHE. This was a common greeting or nickname some years ago, particularly when speaking to children, small boys, etc. It is not in the OED as such. Partridge has it as "a contemptible person" but not as a familiar greeting. We have only one recent example and would welcome any written examples before 2000.

GUTTED. Two Australian visitors arrived recently with a banner headline from the Evening Post which they said would never be seen in Australia:

[Hdg] Mayor gutted by CIT closure... Mr Kirton said he was gutted by yesterday's announcement and 'angry with the management and governance of the CIT over the past few years which allowed them to get into this situation.' [2001 Evening Post $11^{\text {th }}$ April 1]

Kōtare 4, no. 1 (2001), pp. 64-72. 
A quick search of the OED-Online produced no examples for this common New Zealand metaphorical usage, and a further example appeared in the local papers a few days later. I had become convinced that perhaps this was a unique New Zealand usage, only to hear it used in precisely this sense on two recent episodes of Coronation Street.

HOLE-IN-THE-WALLING . The "hole-in-the-wall" has been in use as a slang term for automatic telling machines since at least 1985, but the noun has now become a verb as well.

After all no one got hurt [in a Wellington ATM burglary], it kept us all riveted over the dead holiday period, and hole-in-the-walling in this burgh will never be quite the same again. [2001 Evening Post, $6^{\text {th }}$ Jan., 2]

We would welcome New Zealand examples also of hole-in-the-wall(n).

LODGE. An English wine commentator visiting New Zealand remarked that lodges were a new concept to her. In New Zealand, this term was originally applied to a fishing lodge, but later to a luxury guesthouse, offering good food, wine, recreational fishing and/or shooting, and privacy.

Puka Puka Lodge, nestled in bush overlooking the exclusive coastal community of Pauanui, is a top-dollar resort attracting privacyseeking guests who fly into its helicopter pad. [2000 Dominion $1^{\text {st }}$ Dec. 3]

MONKEY. This is apparently a slang term to describe the action of lighting one cigarette from the (lighted) tip of another. Earlier examples would be appreciated, as would any suggestions about its derivation.

Have a monkey, she says to Joanne, and the ends of their cigarettes touch and Joanne draws in deeply. [2000 Sunday Star-Times $31^{\text {st }}$

Dec. D4]

MUNTED. This, as has been previously mentioned, has at least two meanings - damaged or broken (as used by children) and drunk (as used by adults). Greg Crossan sends us this gem:

Kōtare 4, no. 1 (2001), pp. 64-72. 
I heard a little boy shout to his brother at my son's birthday party about ten years ago: 'Kyle ...Come back here and unmunt my bike!'

NAME BLADES. Greg Crossan also sends us this word for street signs.

Until June 30, the Council's staff looked after the street name "blades", while other road signs were contracted to AA Signs. But when the contract was retendered, the name blades were included in the package won by Horizon Holdings.[2000 Manawatu Evening Standard $22^{\text {nd }}$ Sept. 1]

PLUOT. Here's an interesting sounding new fruit with a name we could well do without.

[Hdg] Plum plus apricots equals pluot. Plums and apricots are coming together nicely at Ray Anna's Marlborough orchard - as pluots... The sweet, juicy fruit, are predominantly plum, with a slight "fuzz" on the skins and an appreciable apricot flavour and texture. They were developed by Californian company Zaiger Genetics 11 years ago using an intricate method of hybridising. [2000 Evening Post 29 $9^{\text {th }}$ Dec. 19]

SALADING. This is one of several strange constructions found by Jan Bunting on a McGregor's lettuce seed packet labeled " Fancy Leaf mixed. Sensational Salading with a Difference." It has a certain usefulness about it for, say, beetroot or cucumber but isn't salading lettuce tautologous? What else is a lettuce used for, except in these days of decorator lettuce, decorating? The term, for salad materials, however, has a long history with its first recorded use in 1664:

1664 EVELYN Kal. Hort. (1729) 190 Sow Chervil, Lettuce, Radish, and other ... Salletings. Ibid. 216 Fill your vacant Beds with Sallading.

Two other "words" from Jan from hairdressing circles have less attraction, mattifying and bodifying. Ugh!

SILVERBEET. Silverbeet has long been a staple vegetable in student flats and other institutions but it was a surprise to find that the OED gives it as Australian and NZ term for a cultivar of the seakale beet, Beta vulgaris cicla, or [Swiss] chard which in turn has been defined as

Kōtare 4, no. 1 (2001), pp. 64-72. 
A member of the beet family with crinkly green leaves and celery-like stalks (either red or white coloured). Leaves and stalk can be eaten raw, or prepared like spinach.

Other names for this vegetable include spinach beet, leaf beet, and chard plant. Our earliest reference to "silver-beet" is a strictly practical one.

In commerce there are eight varieties of Swiss chard or silver-beet. [1913 NZJAg., Jan VI, 595]

Janet Frame seems to have classed it with the other undesirable staples of her childhood.

For dinner I had semolina and silverbeet. [1951 FRAME The Lagoon 98]

Perhaps she would have enjoyed it more, prepared the modern way.

Silverbeet may sound a prosaic choice but boiled until tender then squeezed dry, chopped and pan-fried with olive oil, garlic and chilli it is transformed - and no nasty metallic taste. [2000 Cuisine May, No. $80: 54]$

It's not surprising that when you search on the internet under "silverbeet", the first two entries are to a NZ pop group's 1993 record, "Too Much Silverbeet".

SONNY JIM (also SUNNY JIM). This was a common greeting back in the 1940's and thereabouts, especially for small boys. This has a very interesting background and appears to have originated in the United States. It was later applied to British politician and short-term Prime Minister, Jim Callaghan.

Sunny Jim, the name of an energetic character employed as the proprietary name for a brand of breakfast cereal; also used allusively, as a term of address, and as a nickname. Also Sonny Jim (influenced by SONNY).

According to the OED, 'Sunny Jim was the creation of an American schoolgirl called Ficken (not Fincken) and the various jingles which accompanied him were written by Miss Minnie Hanff. It is believed that Sunny Jim was the winning entry in a competition run by the Force Food Company to find a suitable

Kōtare 4, no. 1 (2001), pp. 64-72. 
advertising character to promote "Force".' C.Fincken (A.C. Fincken \& Co. Ltd., manufacturers of Force), private let. to ed., $24^{\text {th }}$ June 1983.

Citations range from 1903, but we have none from New Zealand

High o'er the fence leaps Sunny Jim. "Force" is the food that raises him. [1903 Poster]

\section{through G.K. Chesterton}

It was like hearing that Sunny Jim had hanged himself. [1911 Chesterton Innocence of Father Brown 315]

to Prime Minister Jim Callaghan.

The new Prime Minister [sc. James Callaghan]...enjoys life ... He is not called Sonny Jim for nothing.[1976 Times, $6^{\text {th }}$ April, 16/1]

TOURISTIFIED. This is my choice for this month's "Word We Could Do Without". It was used by an enthusiast who wants to re-institute the old Gear railway system along the Petone waterfront as a tourist attraction.

Passengers could be carried in converted stock carriages like those that took lambs to the slaughter at the old Gear meat works. An alternative would be "touristified" refrigerated trucks like those that carried carcasses to the wharves.[2000 Evening Post $9^{\text {th }}$ March 18]

Presumably, "tarted up" is not sufficiently PR-friendly.

WINDBREAKER, WINDCHEATER, WIND-JACKET. My English-born wife refers to this light, windproofed jacket with vertical pockets at waist-level as an anorak - I have always called it a windjacket or windbreaker. The garment is probably derived from the WWII US Navy pea-jacket which, although made of much heavier and coarser woollen material, is of similar pattern and is recorded as far back as 1721.

The first meaning given in the OED is "a drug that expels flatulence" but the OED confirms that its secondary use as an item of clothing originated in the US. Windbreaker, at least, is a proprietary name:

Kōtare 4, no. 1 (2001), pp. 64-72. 
the proprietary name of a kind of short or leather blouse; gen.

( chiefly N. Amer.) = windcheater

whereas an anorak is

A weatherproof jacket of skin or cloth, with hood attached, worn by

Eskimos; a similar garment in countries other than Greenland.

Shops throughout New Zealand are now offering for sale "hoodies", which appears to be a new term for hooded, anoraklike woollen garments. \&

Comments can be sent to us at nzdc@vuw.ac.nz or the NZ Dictionary Centre, P.O. Box 600, Wellington.

Kōtare 4, no. 1 (2001), pp. 64-72. 